\title{
Taxonomy and ecology of order Surirellales (Bacillariophyceae) in tropical reservoirs in Southeastern of Brazil
}

\author{
Taxonomia e ecologia da ordem Surirellales (Bacillariophyceae) em reservatórios \\ tropicais no Sudeste do Brasil
}

Krysna Stephanny de Morais ${ }^{1 *}$, Elaine Rodrigues Bartozek ${ }^{2}$, Stéfano Zorzal-Almeida ${ }^{1}$,

\author{
Denise C. Bicudo ${ }^{1}$ and Carlos Eduardo de Mattos Bicudo ${ }^{1}$
}

\begin{abstract}
${ }^{1}$ Laboratório de Ecologia Aquática, Departamento de Ecologia, Instituto de Botânica de São Paulo - IBt, Avenida Miguel Stéfano, 3687, Vila Água Funda, CEP 04301-902, São Paulo,SP, Brasil

${ }^{2}$ Instituto de Biociências, Universidade Estadual Paulista Julio de Mesquita Filho - UNESP, Avenida 24 A, 1515, Bela Vista, CEP 13506-900, Rio Claro, SP, Brasil

*e-mail: krysnamorais@gmail.com
\end{abstract}

Cite as: Morais, K.S. et al. Taxonomy and ecology of order Surirellales (Bacillariophyceae) in tropical reservoirs in Southeastern of Brazil. Acta Limnologica Brasiliensia, 2018, vol. 30, e204.

\begin{abstract}
Aim: The aim of this study was to inventory the diatom species of order Surirellales present in the surface sediments of tropical reservoirs (Sáo Paulo State, Brazil) and to correlate their distribution with environmental ( $\mathrm{pH}$, total phosphorus, and total nitrogen) and spatial predictors. Methods: Samplings were carried out in 31 reservoirs from 2009 to 2014. Vertical profile of water samples was collected in the summer and winter along the reservoirs, and their water column mean results were used to characterize each sampling site. We measured water transparency, euphotic zone, water depth, $\mathrm{pH}$, dissolved oxygen, total nitrogen, and total phosphorus. Surface sediment samples $(2 \mathrm{~cm}$ top) were collected for diatom analyses. A partial RDA was performed between species abundance data (response matrix) and environmental and spatial variables (predictor matrices). Results: 14 species of Surirellales were identified from the surface sediment samples, five of them being identified only at the genus level. Overall, partial RDA showed that the species distribution is constrained by both environmental and spatial predictors. Species were mainly ordinated in relation to $\mathrm{pH}$ and light availability. Conclusion: Our results demonstrated that the Surirellales species revealed ecological preferences to low nutrient concentrations, neutral to slightly acidic waters, and higher light availability. Moreover, our results suggest that both environmental and spatial factors are important for their species distribution.
\end{abstract}

Keywords: surface sediment; Stenopterobia; Surirella; Brazil.

Resumo: Objetivo: O objetivo do estudo foi inventariar as espécies de diatomáceas da ordem Surirellales presentes em sedimentos superficiais de represas tropicais (Estado de São Paulo, Brasil) e correlacionar sua distribuição com preditores ambientais ( $\mathrm{pH}$, fósforo total e nitrogênio total) e espaciais. Métodos: As amostragens foram realizadas em 31 represas entre 2009 e 2014. Amostras de água foram coletadas no verão e inverno ao longo do perfil vertical da represa e os resultados médios da coluna d'água foram utilizados para caracterizar cada estação amostral. Transparência da água, zona eufótica, profundidade, $\mathrm{pH}$, oxigênio dissolvido e nitrogênio e fósforo totais foram medidos. Sedimentos superficiais foram coletados no inverno aproveitando-se os dois primeiros centímetros para a análise das diatomáceas. Foi realizada RDA parcial entre a abundância das espécies (matriz resposta) e as variáveis ambientais e espaciais (matrizes preditoras). Resultados: Foram identificadas 14 espécies de Surirellales nas amostras de sedimentos superficiais, das quais cinco foram identificadas apenas em nível gênero. A RDA parcial mostrou que a distribuição das espécies é influenciada, em geral, pelos preditores ambientais e espaciais. As espécies foram ordenadas principalmente em relação ao $\mathrm{pH}$ e à 
disponibilidade de luz. Conclusáo: Os resultados demonstraram que as espécies de Surirellales apresentam preferência por ambientes com baixa concentração de nutrientes, águas neutras a levemente ácidas e maior disponibilidade de luz. Além disso, os resultados sugerem que fatores espaciais e ambientais são importantes na distribuição das espécies.

Palavras-chave: sedimento superficial; Stenopterobia; Surirella; Brasil.

\section{Introduction}

The order Surirellales is mainly characterized by solitary cells with a canal raphe system often raised by a keel. Such canal raphes are usually found in the valve margin and may be raised by wings or keels (Ruck \& Theriot, 2011). The presence of a "keeled" raphe is important to improve structural stability between the canal raphe and substrate such as unconsolidated sediments (Round et al., 1990). Surirellales comprise more than 1.300 nominal species (Fourtanier \& Kociolek, 2011), and includes three families (Entomoneidaceae, Auriculaceae and Surirellaceae) and 10 genera (Ruck et al., 2016), which occur in a variety of freshwater, estuarine and marine ecosystems, with some species entirely restricted to acidic waters (Lowe, 2003).

In Brazil, 62 species and 19 varieties were reported in the literature (Eskinazi-Leça et al., 2015, Menezes et al., 2015). Nevertheless, this still is a poorly known diatom group in terms of taxonomical and ecological features, since they are usually recorded in floristic surveys (Silva et al., 2010; Bartozek et al., 2013) or mentioned in ecological studies without detailed information about the species (Bortolini \& Bueno, 2013; Rosa \& Garcia, 2015) with few taxonomic studies (Torgan \& Weber 2008; Salomoni \& Torgan 2010; Oliveira et al., 2012).

For the state of Sáo Paulo, 15 species were reported and nine new records for the Parque Estadual das Fontes do Ipiranga were recently registered by Ferreira \& Bicudo (2017): Stenopterobia delicatissima (F.W.Lewis) L.A. Brébisson ex H. van Heurck, S. pelagica F.Hustedt, S. planctonica D. Metzeltin \& H. Lange-Bertalot, S. curvula (W.Smith) K. Krammer, Surirella angusta F.T.Kützing, S. guatimalensis C.G.Ehrenberg, S. stalagma M.H.Hohn \& J.Hellerman, S. splendida (C.G.Ehrenberg) F.T.Kützing and S. tenera W.Gregory.

The ecological studies about Surirellales for tropical and subtropical regions are still very scarce and address $\mathrm{pH}$ preferences, trophic state, and physical and chemical water parameters (e.g. Cocquyt et al., 2014; Cocquyt \& Taylor, 2015; Cocquyt et al., 2017). This is partially because most ecological studies considered Surirellales rare taxa in terms of abundance and/or occurrence and, therefore, exclude them from further analysis. Nevertheless, rare taxa may constitute the largest component of species richness in an assemblage (Marchant et al., 1997; Gillett et al., 2011) being, therefore, important components of biodiversity. Furthermore, rare taxa are expected to have narrow ecological niches and to be sensitive to anthropogenic impacts (Gillett et al., 2011).

Besides identifying which environmental factors are influencing species distribution, another important issue is to know whether such species are being constrained by geographical factors that limit species dispersion (Potapova \& Charles, 2002). Thus, the study of ecological preferences and distribution of diatoms based on taxonomy and ecological information is important for their successful use, for instance, in water quality bioassessment (Ponader et al., 2007) and to understand the anthropogenic influence on freshwater ecosystems (Dudgeon et al., 2006; Smith et al., 2006).

The present study uses a large data set on tropical reservoirs from southeastern Brazil, covering a wide range of trophic states (from oligo to hypereutrophic) to describe the diversity of Surirellales species and to expand their ecological information. Thus, the objective of this study is (1) to identify and describe the main Surirellales species occurring in surface sediments samples from tropical reservoirs, and (2) to correlate then to environmental factors ( $\mathrm{pH}$, total phosphorus and total nitrogen) and spatial predictors. This information would be very important to improve the understanding about the distribution and ecological preferences of Surirellales species, which still is a poorly known diatom group in terms of ecological features in tropical regions.

\section{Material and Methods}

\subsection{Study area}

The state of São Paulo has a total area of $248.222 .362 \mathrm{~km}^{2}$, which is equivalent to $3 \%$ of the Brazilian territory (IBGE, 2017). Climate is tropical with dry winter and rainy summer and annual average temperature between $18-22^{\circ} \mathrm{C}$ (CEPAGRI, 2015). This study was carried out in 31 reservoirs (123 sampling sites) located in five drainage basins of the Northeast São Paulo (Upper Tietê, Medium 
Tietê/Upper Sorocaba, Piracicaba River Basin, Upper Paranapanema and Ribeira do Iguape and Litoral; Figure 1). The reservoirs range from small to large area (0.2-18.9 $\left.\mathrm{km}^{2}\right)$, oligo- to eutrophic conditions, acidic to slightly alkaline ( $\mathrm{pH}$ : 5.2-8.2) and with different land uses (recreational, power, public water supply). One to five sampling sites were placed in each reservoir, and the number of sites and their position was chosen considering the maximum depth (dam zone) and size of the reservoirs, as well as the position of the main tributaries.

\subsection{Sampling and samples treatment}

Samplings were carried out from 2009 to 2014. Water samples were collected during the summer and winter with a van Dorn bottle along the reservoir vertical profile (subsurface, mean depth and $1 \mathrm{~m}$ above the sediments), and the mean values of the water column were used to characterize each sampling site. The following variables were measured: water transparency (based on Secchi disk), water depth, $\mathrm{pH}$ (Horiba U-50), dissolved oxygen (DO, $\left.\mathrm{mg} \mathrm{L}^{-1}\right)$, total nitrogen $\left(\mathrm{TN}, \mu \mathrm{g} \mathrm{L}^{-1}\right)$ and total phosphorus (TP, $\mu \mathrm{g} \mathrm{L}^{-1}$ ), according to Standard Methods (APHA, 2005). Euphotic zone $\left(\mathrm{Z}_{\mathrm{eu}}\right)$ was calculated multiplying the water transparency value by 2.7 (Esteves, 1998). Surface sediment samples were collected using a gravity core, saving the top $2 \mathrm{~cm}$ section for diatom analyses.

Sediment samples were cleaned for diatom analysis according to Battarbee et al. (2001) using $35 \% \mathrm{H}_{2} \mathrm{O}_{2}$ and $37 \% \mathrm{HCl}$ at $80{ }^{\circ} \mathrm{C}$. Permanent slides were mounted using Naphrax. Optical microscopy analysis was performed using a Zeiss Axio Imager A2 equipped with Differential Interference Contrast (DIC) and a high-resolution digital camera (MRC5) under 1000x magnification. Taxonomic study was carried out after population analysis and measurement of length (L), width (W), number of striae (S), fibula (F), ribs (R), wing projection (WP) and alar canals (AC) in $10 \mu \mathrm{m}$. Species identification followed classic works and recent publications (e.g. Hustedt, 1985; Krammer \& Lange-Bertalot, 1991; Lange-Bertalot \& Metzeltin, 1996; Cocquyt \& Jahn, 2005), and the online catalogue of valid names (California Academy of Sciences, 2012). Terminology of valve morphology was based on Ross et al. (1979) and Barber \& Haworth (1981). Taxonomic framing was based on Medlin \& Kaczmarska (2004) for

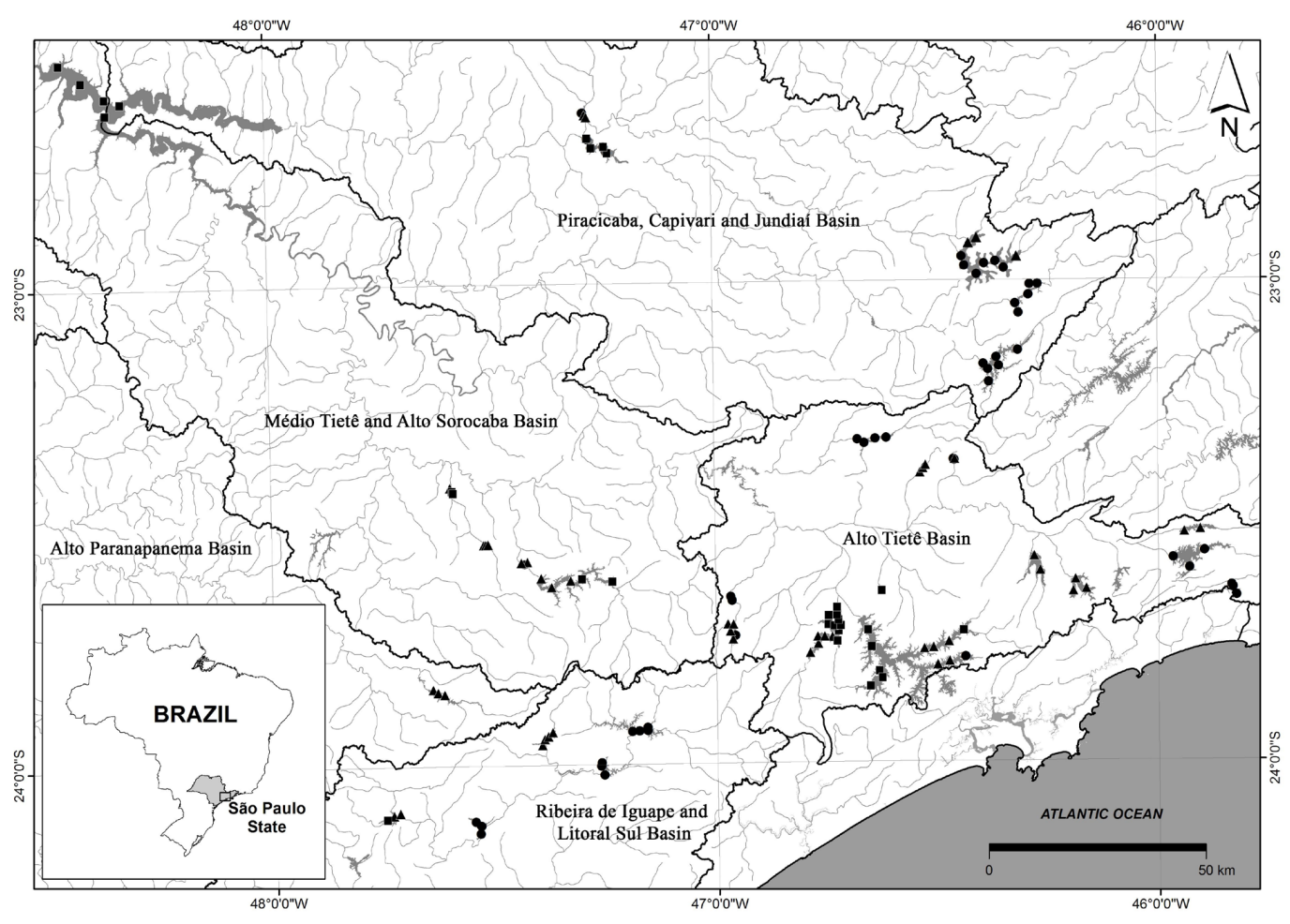

Figure 1. Map with the location of the 31 reservoirs studied (Southeastern Brazil). Black circles represent oligotrophic sampling sites, black triangles represent mesotrophic sampling sites, and black squares represent eutrophic sampling sites. Adapted from Bicudo et al. (2016). 
supra-ordinal categories and Round et al. (1990) for subordinal categories. Sediment samples were deposited in the "Herbário Científico do Estado Maria Eneyda P. Kauffmann Fidalgo" (SP), Brazil. Finally, at least 400 valves were counted per slide at $1000 \times$ magnification using a Zeiss Axioskop 2 to determine species richness and abundance (Battarbee et al., 2001). Species abundances were expressed as a percentage of the total diatom counts in each sample. Diatom species codes followed the OMNIDIA software (Lecointe et al., 1993).

\subsection{Numerical analysis}

Based on the available literature (e.g. ZorzalAlmeida et al., 2017b; Bicudo et al., 2016; Virtanen \& Soininen, 2012), light availability (euphotic zone: depth ratio), total phosphorus, total nitrogen and molar N:P ratio were selected as the environmental predictors. These variables were log-transformed prior to the analysis (except $\mathrm{pH}$ ). Principal Coordinates of Neighbor Matrices (PCNM) were used to obtain the spatial variables (Dray et al., 2006). This method uses geographic coordinates of each sampling site, calculates Euclidian distances (overland distances) among sites and produce orthogonal spatial variables to be used as spatial predictors in the canonical analysis (Borcard et al., 2011). Partial Redundancy Analysis (partial RDA) (Figure 2) was used to evaluate the variation within the diatom data set that could be explained by environmental variables without spatial effects. Variation partitioning was used to compute the pure effect of the environmental and spatial predictors in the variation of each taxon and for all diatom data set. This analysis disregards the

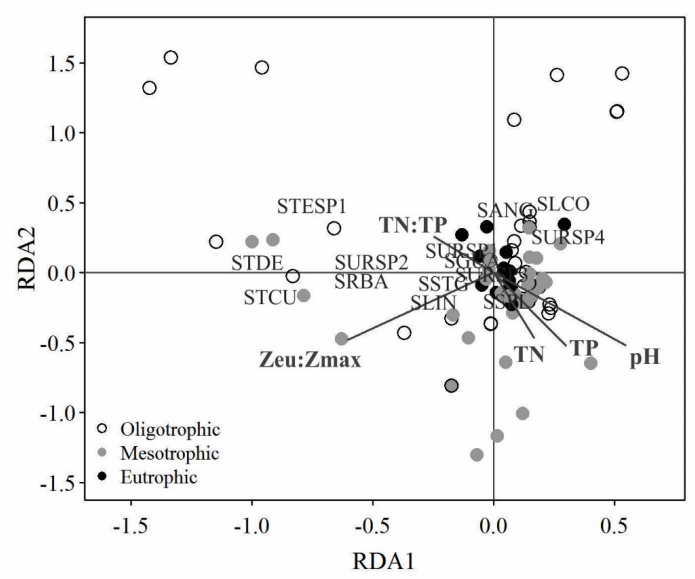

Figure 2. Results of partial RDA for the 14 Surirellales species from surface sediments. Environment variables codes are available in Table 1 and species codes in Table 3. spatial contribution of the environmental data, and vice-versa, allowing access to the contribution of pure environmental and spatial predictors on the species variation (Peres-Neto \& Legendre, 2010). All these statistical analyses were performed using the program R 3.3.1 (R Core Team, 2016) and the packages PCNM (Legendre et al., 2009) and vegan (Oksanen et al., 2017).

\section{Results and Discussion}

Our finding reports 14 taxa distributed in two genera and one taxonomic variety of the family Surirellaceae, order Surirellales. We presently found three taxa of Stenopterobia (Figure 3-10) and 11 of Surirella (Figure 11-33) . Five taxa were identified at the genus level and most likely represent new species. Below is included the taxonomical aspects of all infrageneric taxa and their ecological features according to the available literature for the group and those found in this study, as follows.

Reservoirs ranged from oligotrophic to eutrophic (Table 1), acidic to alkaline and low to high dissolved oxygen. Based on counting analysis, taxa of Surirellales were found in low abundances and frequency of occurrence in all samples (Table 2) and only in oligo- and mesotrophic reservoirs. Surirella roba was the most abundant species with $4.7 \%$ in the oligotrophic reservoir Cachoeira da Graça (Alto Tietê basin, pH 6.4), followed by Stenopterobia curvula with $4.0 \%$ in the mesotrophic reservoir Pedro Beicht (Alto Tietê basin, pH 6.1-6.2) (Table 2).

Stenopterobia Brébisson ex van Heurck

Stenopterobia curvula (W.Smith) K.Krammer, Bibliotheca Diatomologica 15: 108, pl. 58, fig. 1-4. 1987.

Figures 3-5

Valve isopolar, symmetric, sigmoid; valve ends rounded; axial area hyaline and narrow; ribs absent; fibulae parallel; striae visible, parallel. L: 130.7-176.4 $\mu \mathrm{m}$; W: 6.6-7.2 $\mu \mathrm{m}$; L/W: 19.9-24.4; F: $5-6$ in $10 \mu \mathrm{m}$; S: $19-22$ in $10 \mu \mathrm{m}$.

S. curvula can be also distinguished from Stenopterobia anceps ssp. gigantea Metzeltin \& Lange-Bertalot (2005) mainly due to the larger populations measures of the second species (L: $450.0 \mu \mathrm{m}$, W: $17.5 \mu \mathrm{m}$ ) and narrower valve poles of $S$. curvula.

Ecology: It was reported in $5.7 \%$ of the samples in oligo- and mesotrophic reservoirs, with water transparency ranging from 0.5 to $2.1 \mathrm{~m}$ and $\mathrm{pH}$ from 5.4 to 6.2 .

Distribution: BRAZIL, São Paulo: Alto Tietê basin, Cachoeira da Graça reservoir, S 2339.779’ 
W4657.928', P.D.A. Silva \& D.C. Bicudo Beicht reservoir, S 2344.946' W 4657.660', (SP427583); S 2339.290’ W 4657.784',

P.D.A. Silva \& D.C. Bicudo (SP427578); $23^{\circ} 44.008^{\prime}$ P.D.A. Silva \& D.C. Bicudo (SP427584); Pedro

W 4657.409', P.D.A. Silva \& D.C. Bicudo


22

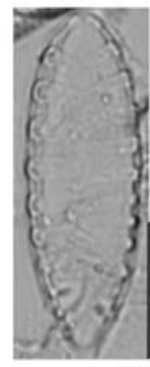

13
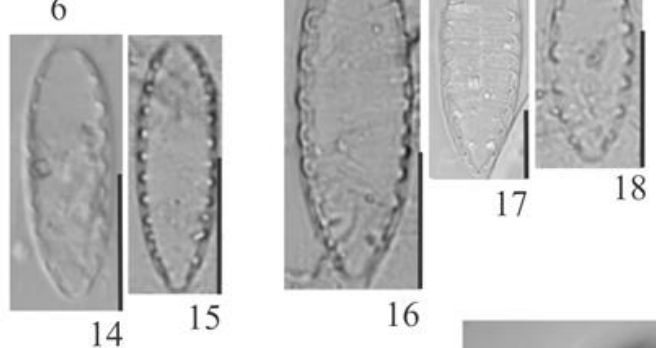

\section{.}



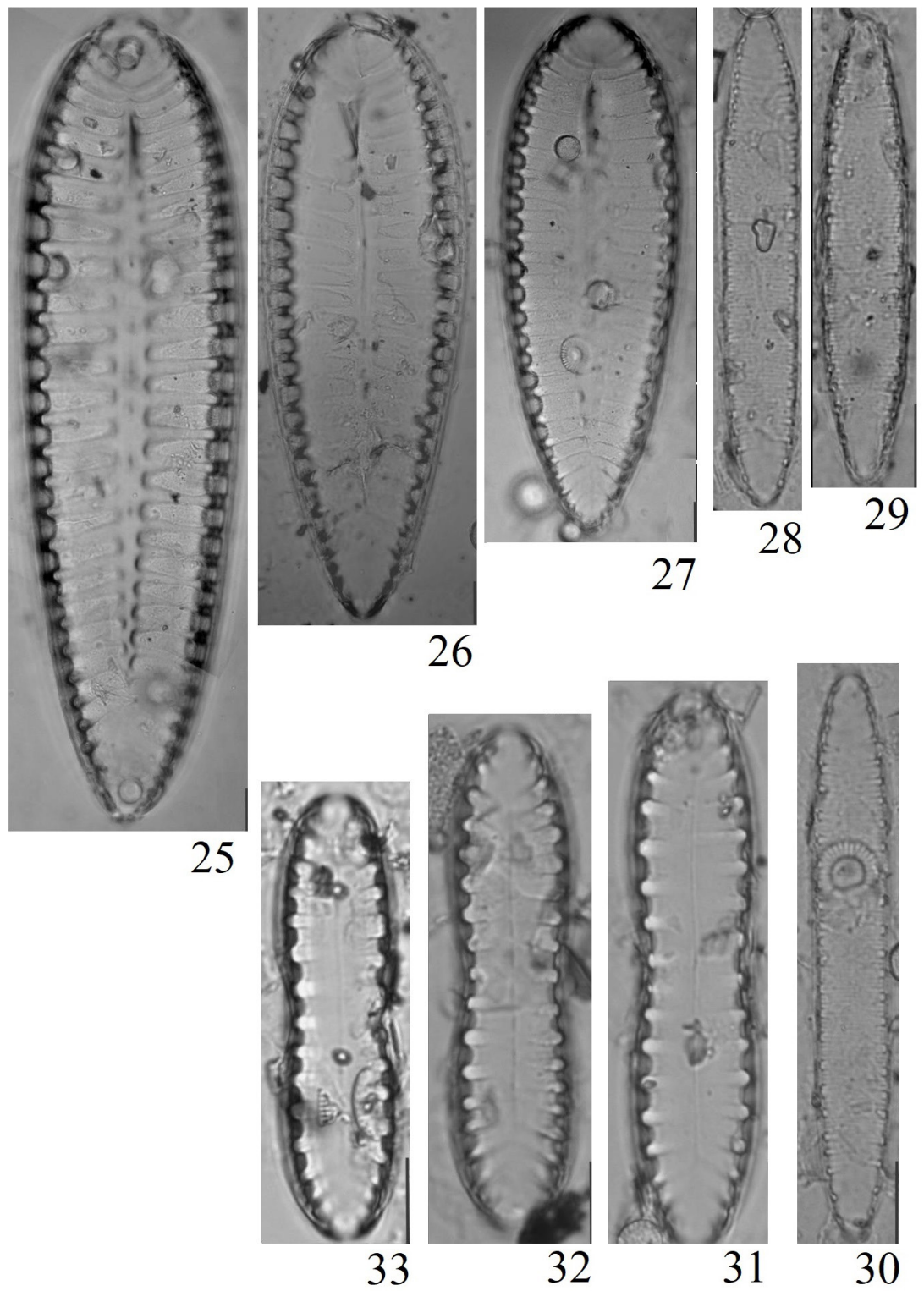

30

Figures 25-33. Surirellales from surface sediments, São Paulo state. Brazil. Scale bar: $10 \mu \mathrm{m}$. 25-27. Surirella splendida. 28-30. Surirella sp. 1. 31-33. Surirella linearis var. constricta.

(SP427579); S 2343.048’ W 4657.676', P.D.A. Silva \& D.C. Bicudo (SP427580); S 2344.095' W 46587.160', P.D.A. Silva \& D.C. Bicudo (SP427581); S 2343.000' W 4658.647', P.D.A. Silva \& D.C. Bicudo (SP427582); Ribeirão do Campo reservoir, S 2339'31.8” W 4549'23.2”, A.C.R. Rocha \& D.C. Bicudo (SP468841); S 2338'30.8” W 4549'51.2", A.C.R. Rocha \& D.C. Bicudo (SP468842); S2338'15.2” W4550'0.78”, A.C.R. Rocha \& D.C. Bicudo (SP468843).

Stenopterobia delicatissima (F.W.Lewis) L.A.Brébisson ex H.van Heurck, A treatise on the Diatomaceae: 374, figs. 19-51. 1986.

Figure 6
Valve isopolar, symmetric, elliptical-lanceolate; pointed apices; axial area hyaline and narrow; ribs absent; alar canals delicate; fibulae delicate; striae parallel, delicate. L: $46.1 \mu \mathrm{m}$; W: $3.0 \mu \mathrm{m}$; L/W: 15.6; F: $4-5$ in $10 \mu \mathrm{m}$; S: $24-26$ in $10 \mu \mathrm{m}$; AC: 11 in $10 \mu \mathrm{m}$.

S. delicatissima differs from Stenopterobia chilensis Metzeltin \& Lange-Bertalot (2005) mainly because the second species is wider (W: 7.5-8.5 $\mu \mathrm{m}$ ) and presents smaller density of alar canals (4.5-5.5 in $10 \mu \mathrm{m})$.

Ecology: S. delicatissima is considered a cosmopolitan oligo-mesotrophic species (Krammer \& Lange-Bertalot, 1988), existing in acidic waters 
Table 1. Mean (minimum-maximum) of the environmental variables measured in the sampled reservoirs $(\mathrm{n}=123$ sites).

\begin{tabular}{lcccc}
\hline & All reservoirs & $\begin{array}{c}\text { Oligotrophic } \\
\text { reservoirs }\end{array}$ & $\begin{array}{c}\text { Mesotrophic } \\
\text { reservoirs }\end{array}$ & $\begin{array}{c}\text { Eutrophic } \\
\text { reservoirs }\end{array}$ \\
\hline Depth $(\mathrm{m})$ & 11.4 & 16.4 & 8.3 & 9.0 \\
Water transparency $(\mathrm{m})$ & $(0.5-42.5)$ & $(0.5-39.5)$ & $(0.8-42.5)$ & $(3.0-18.0)$ \\
& 1.7 & 2.2 & 1.5 & 1.1 \\
Light penetration & $(0.3-4.2)$ & $(0.5-4.2)$ & $(0.5-2.9)$ & $(0.3-1.5)$ \\
& 0.5 & 0.5 & 0.6 & 0.4 \\
pH & $(0.1-1.0)$ & $(0.2-1.0)$ & $(0.1-1.0)$ & $(0.1-1.0)$ \\
& 6.7 & 6.3 & 6.6 & $(6.6-8.2)$ \\
DO $\left(\mathrm{mg} \mathrm{L}^{-1}\right)$ & $(5.2-8.2)$ & $(5.2-7.3)$ & $(5.8-7.6)$ & 5.5 \\
& 5.7 & 5.8 & 5.7 & $(2.3-10.7)$ \\
TN $\left(\mu \mathrm{g} \mathrm{L}{ }^{-1}\right)$ & $(2.3-10.7)$ & $(3.7-8.6)$ & $(3.3-7.2)$ & 2452.9 \\
& 966.9 & 340.9 & 625.1 & $(400.3-10209.5)$ \\
TP $\left(\mu \mathrm{g} \mathrm{L}{ }^{-1}\right)$ & $(152.0-10209.5)$ & $(152.0-770.4)$ & $(163.1-1735.7)$ & 101.8 \\
& 37.8 & 10.1 & 23.9 & $(25.4-442.1)$ \\
N:P & $(4.0-442.1)$ & $(4.0-24.5)$ & $(11.7-81.2)$ & 69.0 \\
molar ratio & 78.7 & 95.8 & 68.7 & $(28.7-170.4)$ \\
\hline
\end{tabular}

Table 2. Surirellales relative abundance and frequency of occurrence in samples $(\mathrm{n}=123$ sites). Species codes according to OMNIDIA (except for material at generic level).

\begin{tabular}{lccc}
\hline \multicolumn{1}{c}{ Species } & Species codes & Abundance (\%) & Frequency of occurrence (\%) \\
\hline Stenopterobia curvula & STCU & $0.0-4.0$ & 5.7 \\
Stenopterobia delicatissima & STDE & $0.0-0.4$ & 6.5 \\
Stenopterobia sp. 1 & STESP1 & $0.0-3.0$ & 2.4 \\
Surirella angusta & SANG & $0.0-0.3$ & 0.8 \\
Surirella guatimalensis & SGUA & $0.0-0.2$ & 0.8 \\
Surirella linearis var. linearis & SLIN & $0.0-0.8$ & 0.8 \\
Surirella linearis var. & SLCO & $0.0-0.2$ & 1.6 \\
constricta & & & \\
Surirella roba & SRBA & $0.0-4.7$ & 0.8 \\
Surirella splendida & SSPL & $0.0-0.3$ & 3.2 \\
Surirella stalagma & SSTG & $0.0-0.4$ & 0.8 \\
Surirella sp. 1 & SURSP1 & $0.0-0.5$ & 0.8 \\
Surirella sp. 2 & SURSP2 & $0.0-0.4$ & 1.6 \\
Surirella sp. 3 & SURSP3 & $0.0-0.5$ & 1.6 \\
Surirella sp. 4 & SURSP4 & $0.0-0.2$ & 1.6 \\
\hline
\end{tabular}

(Lowe, 2003). In our study, this species was distributed in $6.5 \%$ of all samples and exclusively found in oligotrophic conditions, with water transparency ranging from 0.5 to $2.0 \mathrm{~m}$ and $\mathrm{pH}$ of 5.4 .

Distribution: BRAZIL, São Paulo: Alto Tietê basin, Ribeirão do Campo reservoir, S 2338'30.8” W 45\%49'51.2", A.C.R. Rocha \& D.C. Bicudo (SP468842); S2338'15.2” W45'50'0.78”, A.C.R. Rocha \& D.C. Bicudo (SP468843).

Figures 7-10

\section{Stenopterobia sp. 1}

Valve isopolar, symmetric, linear to linear-lanceolate; pointed apices; axial area hyaline and narrow; ribs absent; fibulae parallel; striae visible, parallel. L: 69.4-81.2 $\mu \mathrm{m}$; W: 8.7-9.5 $\mu \mathrm{m}$; S: $11-16$ in $10 \mu \mathrm{m}$; L/W: $7.3-8.8$; AC: $4-5$ in $10 \mu \mathrm{m}$; F: $10-12$ in $10 \mu \mathrm{m}$.

Regarding the valve shape, the present material resembles Stenopterobia hulli Metzeltin \& Lange-Bertalot (2005). However, the latter presents populations with smaller values of width (7-7.5 $\mu \mathrm{m})$. In addition, $S$. hulli has valves fusiform and short protracted ends.

Ecology: This taxon occurred in $2.4 \%$ of samples in oligo and mesotrophic conditions, with water transparency ranging from 0.7 to $1.5 \mathrm{~m}$ and $\mathrm{pH}$ from 6.1 to 6.2 . 
Table 3. Results of partial RDA analysis and ecological range for each species.

\begin{tabular}{|c|c|c|c|c|c|c|c|}
\hline & \multicolumn{5}{|c|}{ Partial RDA } & \multicolumn{2}{|c|}{ Ecological range } \\
\hline & & & & & & TN & TP \\
\hline & Env & $E+5$ & spa & Res & pH & $\left(\mu \mathrm{g} \mathrm{L}^{-1}\right)$ & $\left(\mu \mathrm{g} \mathrm{L}^{-1}\right)$ \\
\hline Stenopterobia curvula & 0.08 & 0.10 & 0.26 & 0.55 & $6.1-6.2$ & $163.1-278.8$ & $9.6-15.7$ \\
\hline Stenopterobia delicatissima & 0.25 & 0.00 & 0.02 & 0.73 & $5.4-6.2$ & 163.1-418.6 & $4.0-15.0$ \\
\hline Stenopterobia sp. 1 & 0.17 & 0.02 & 0.15 & 0.65 & 5.4 & $292.7-425.6$ & $4.0-4.4$ \\
\hline Surirella angusta & 0.01 & --- & --- & 1.00 & 6.1 & 218.7 & 14.7 \\
\hline Surirella guatimalensis & --- & 0.01 & --- & 1.00 & 6.5 & 586.8 & 14.8 \\
\hline Surirella linearis var. linearis & 0.00 & 0.00 & 0.06 & 0.95 & 7.6 & 1185.9 & 81.2 \\
\hline Surirella linearis var. constricta & 0.01 & 0.02 & --- & 1.00 & $6.0-6.4$ & 201.8-360.2 & $12.3-24.5$ \\
\hline Surirella roba & 0.29 & --- & 0.18 & 0.55 & $6.1-6.2$ & 163.1-278.8 & $9.6-15.7$ \\
\hline Surirella splendida & --- & --- & 0.08 & 0.94 & $6.6-6.8$ & $305.4-355.4$ & $17.1-18.0$ \\
\hline Surirella stalagma & --- & 0.01 & --- & 1.00 & $6.7-6.9$ & $284.5-748.7$ & $19.1-25.5$ \\
\hline Surirella sp. 1 & 0.02 & --- & 0.08 & 0.95 & 6.4 & 305.5 & 10.2 \\
\hline Surirella sp. 2 & 0.09 & 0.01 & --- & 0.92 & 5.2 & 465.5 & 4.0 \\
\hline Surirella sp. 3 & 0.00 & 0.02 & --- & 1.00 & 7.0 & 410.7 & 35.2 \\
\hline Surirella sp. 4 & 0.04 & 0.02 & --- & 0.96 & $6.9-7.1$ & 167.3-203.7 & 8.1-11.6 \\
\hline
\end{tabular}

Env: environmental variables, Spa: spatial variables, E+S: environmental and spatial variables, Res: residual, TN: total nitrogen, TP: total phosphorus. Species codes in Table 2. Bold numbers in partial RDA are significant results $(P>0.05)$. Negative results in partial RDA are not shown.

Distribution: BRAZIL, São Paulo: Alto Tietê basin, Cachoeira da Graça reservoir, S 2339.779’ W46 57.928', P.D.A. Silva \& D.C. Bicudo (SP427583); S 23³9.290' W 46057.784', P.D.A. Silva \& D.C. Bicudo (SP427584); Pedro Beicht reservoir, S $23^{\circ} 44.008^{\prime} \mathrm{W} 46^{\circ} 57.409^{\prime}$, P.D.A. Silva \& D.C. Bicudo (SP427579); S 2343.048' W 4657.676', P.D.A. Silva \& D.C. Bicudo (SP427580); S 2344.095' W 46587.160', P.D.A. Silva \& D.C. Bicudo (SP427581); S 2343.000' W 4658.647', P.D.A. Silva \& D.C. Bicudo (SP427582).

\section{Surirella Turpin}

Surirella angusta F.T.Kützing, Die Kieseslchaligen Bacillarien oder Diatomeen. 61, pl. 30, fig. 52. 1844.

Figures 11-12

Valve isopolar, symmetric, isobilateral, linear to linear-lanceolate; keel low; valve ends cuneate-rounded; axial area hyaline and narrow; ribs absent; wings projection absent; fibulae absent; costae raised; striae dense. L: 31.8-33.4 $\mu \mathrm{m}$; W: 7.1-7.3 $\mu \mathrm{m}$; L/W: 4.5-4.6; inconspicuous striae; C: $8-9$ in $10 \mu \mathrm{m}$.

S. angusta differs from Surirella antioquiensis S.E. Sala, J.J. Ramírez, Plata-Díaz \& Vouilloud (2012) mainly due to its larger valve dimensions (S. antioquiensis L: 14.0-32.0 $\mu \mathrm{m}$ ). According to Sala et al. (2013), these species are different mainly due to the striae pattern (uniseriate in S. antioquiensis and multiseriate in S. angusta), ribs (narrow and visible in $S$. antioquiensis) and axial area (broad in S. antioquiensis).
Ecology: This is a cosmopolitan species reported in alkaline waters (Hustedt, 1938). Metzeltin \& Lange-Bertalot (2005) found S. angusta in eutrophic lakes with high conductivity. Presently, it was found in $0.8 \%$ of all samples in oligotrophic conditions, with water transparency of $1.1 \mathrm{~m}$ and $\mathrm{pH}$ of 6.1.

Distribution: BRAZIL, São Paulo: Alto Tietê basin, Paiva Castro reservoir, S 23' $19^{\prime} 43^{\prime \prime}$ W 46³8'11", S.Z. Almeida \& D.C. Bicudo (SP469260).

Surirella guatimalensis C.G.Ehrenberg, Mikrogeologie: das erden und felsen schaffende Wirken des unsichtbar kleinen selbstständigen Lebens auf der Erde. 19, pl. 33, fig. 7. 1854.

Figure 24

Valve heteropolar, asymmetric; keel low; apical pole broadly rounded, basal pole rounded; axial area elongated; ribs absent; wings projection absent; fibulae visible, short. L: $139.5 \mu \mathrm{m}$; W: $62.8 \mu \mathrm{m}$; L/W: 2.2; striae inconspicuous; F: 8 in $10 \mu \mathrm{m}$.

This species is very similar to Surirella davidsonii Schmidt regarding its valve outline. However, S. davidsonii usually presents populations with smaller dimensions (L: 90.0-138.0 $\mu \mathrm{m}$; W: 33.0-60.0 $\mu \mathrm{m}$ ) and the presence of a linear axial area (Oliveira et al., 2012).

Ecology: Reported in tropical freshwater ecosystems with low water current (Rivera, 1974). In the present study, the species was found in $0.8 \%$ of all samples in mesotrophic conditions, with water transparency of 2.6 and $\mathrm{pH}$ of 6.5 .

Distribution: BRAZIL, São Paulo: Alto Tietê basin, Cabuçu reservoir, S 2324'00.6" 
W 46³1'56.6”, S.A. Oliveira, D.C. Bicudo \& C.E.M. Bicudo (SP428923).

Surirella linearis var. linearis W.Smith, A Synopsis of the British Diatomaceae. 31, pl. 8, fig. 58. 1853.

Figures 22-23

Valve isopolar, symmetric, linear to linear-lanceolate; keel high; valve ends cuneate; axial area narrow; ribs parallel; wings projection parallel; fibulae absent; valve face ornamented with undulations; presence of small countless striae in valve face. L: 125.3-128.1 $\mu \mathrm{m}$; W: 31.7-33.2 $\mu \mathrm{m}$; L/M: 3.8-4.0; inconspicuous striae; R: 4 in $10 \mu \mathrm{m}$; WP: 4 in $10 \mu \mathrm{m}$.

S. linearis var. linearis differ from $S$. linearis var. constricta Grunow due to the absence of a constriction in the mid portion of valves (LangeBertalot, 2004).

Ecology: It is a cosmopolitan species (Foged, 1981), acidophilic (Schoeman, 1973) with $\mathrm{pH}$ optimum 6.0, common in rivers, springs and water tanks (Cholnoky, 1952). In the present study, $S$. linearis occurred in $0.8 \%$ of all samples in mesotrophic conditions, with water transparency of $0.5 \mathrm{~m}$ and $\mathrm{pH}$ of 7.6.

Distribution: BRAZIL, São Paulo: Alto Tietê basin, Cachoeira da Graça reservoir, S 2339.779' W 4657.928', P.D.A. Silva \& D.C. Bicudo (SP427583); S 2339.290' W 46 57.784', P.D.A. Silva \& D. C. Bicudo (SP427584). Médio Tietê/Alto Sorocaba basin, Hedberg reservoir, S 23 $25^{\prime} 55.86$ W 470 35' 33.06”, E.C.R. Bartozek \& D.C. Bicudo (SP469240).

Surirella linearis var. constricta A.Grunow, Verhandlungen der Kaiserlich-Königlichen Zoologisch-Botanischen Gesellschaft in Wien 12: 455, pl. 18. 1862.

Figures 31-33

Valve isopolar, symmetric, isobilateral; keel high; valve poles broadly rounded; axial area hyaline, narrow; ribs parallel; wings projection distinct, parallel; fibulae absent. L: 52.6-65.4 $\mu \mathrm{m}$; W: 14.3-14.5 $\mu \mathrm{m}$; L/M: 3.7-4.5; inconspicuous striae; R: 3 in $10 \mu \mathrm{m}$; WP: 2 in $10 \mu \mathrm{m}$.

This species is very similar to Surirella dydima Kützing in its valve outline. However, they are different because $S$. dydima has valve poles cuneate (Kützing 1844).

Ecology: This is a cosmopolitan species reported in freshwater environments with $\mathrm{pH}$ optimum in alkaline waters (Frenguelli, 1941). Nevertheless, Metzeltin et al. (2005) registered this species in acidic or slightly acidic waters. During the present study, $S$. linearis var. constricta was found in $1.6 \%$ of all samples in oligotrophic systems, with water transparency ranging from 1.5 to 1.6 and $\mathrm{pH}$ from 6.0 to 6.4 .

Distribution: BRAZIL, São Paulo: Piracicaba, Capivari e Jundiaí basin, Cachoeira reservoir, S 2300'35" W 46¹6'05", S.Z. Almeida \& D.C. Bicudo (SP469248); Alto Tietê basin, Paiva Castro reservoir, S 2320'15" W 46³9'41", S.Z. Almeida \& D.C. Bicudo (SP469261).

Surirella roba L.Leclercq (1983), Bulletin du Jardin Botanique National de Belgique 53(3-4): 491-505.

Figure 13

Valve heteropolar, elliptic; keel short; apical pole broadly rounded, base pole cuneate; axial area narrow; wings projection parallel; fibulae absent. L: $45.8 \mu \mathrm{m}$; W: $12.4 \mu \mathrm{m}$; L/M: 3.7; striae inconspicuous; WP: 3 in $10 \mu \mathrm{m}$.

This species differs from Surirella linearis Smith due to its smaller populations and smaller number of wings projection in $10 \mu \mathrm{m}$ (Krammer \& Lange-Bertalot, 1991: S. linearis: L: 107.5-140.8 $\mu \mathrm{m}$; WP: 4-6 in $10 \mu \mathrm{m})$.

Ecology: Registered in oligotrophic waters (Krammer \& Lange-Bertalot, 1991). In the present study, the species occurred in $0.8 \%$ of all samples in oligo and mesotrophic conditions, with water transparency ranging from 0.7 to $1.4 \mathrm{~m}$ and $\mathrm{pH}$ from 6.1 to 6.2 .

Distribution: BRAZIL, São Paulo: Alto Tietê basin, Cachoeira da Graça reservoir, S 2339.779' W4657.928', P.D.A. Silva \& D.C. Bicudo (SP427583); S 23³9.290' W 4657.784', P.D.A. Silva \& D.C. Bicudo (SP427584).

Surirella splendida (C.G.Ehrenberg) F.T. Kützing, Die Kieselschaligen Bacillarien oder Diatomeen. 62, pl. 7, fig. 9. 1844.

Figures 25-27

Valve heteropolar, asymmetric; keel high; apical pole broadly rounded, basal pole cuneate; axial area hyaline, lanceolate with 1 spine; ribs parallel; wings projection parallel; fibulae absent. L: 122-189.9 $\mu \mathrm{m}$; W: 42.7-52 $\mu \mathrm{m}$; L/M: 2.9-3.6; striae inconspicuous; R: 4-6 in $10 \mu \mathrm{m}$; WP: 2-6 in $10 \mu \mathrm{m}$.

This species is very similar to Surirella tenera Gregory in Krammer \& Lange-Bertalot (1988) regarding the valve outline and the presence of a spine at the apical pole. However, S. splendida presents larger valve dimensions than $S$. tenera (L: $84.0-140.8 \mu \mathrm{m}$; W: 30.7-40.8 $\mu \mathrm{m}$ ) and basal pole slightly cuneate (Krammer \& Lange-Bertalot, 1988).

Ecology: It is considered a cosmopolitan, benthonic and planktonic species. It can be found in coastal areas, especially in the margin of rivers (Frenguelli, 1941; Cholnoky, 1952; Hustedt, 1957). 
We have presently recorded the occurrence of S. splendida in $3.2 \%$ of all samples in mesotrophic waters, with water transparency ranging from 1.9 to 2.3 and $\mathrm{pH}$ from 6.6 to 6.7 .

Distribution: BRAZIL, São Paulo: Alto Tietê basin, Cabuçu reservoir, S 23⒉'25.6" W 4631'42.8”, S.A. Oliveira, D.C. Bicudo \& C.E.M. Bicudo (SP428921); Ribeira do Iguape and Litoral Sul basin, Salto do Iporanga reservoir, S 2406'15.0" W 4744'06.0”, G.C. Marquardt \& D.C. Bicudo (SP469418).

Surirella stalagma M.H.Hohn \& J.Hellerman, Transactions of the American Microscopical Society 82: 327, pl. 4, fig. 6. 1963.

Figures 19-20

Valve heteropolar, spatulate; keel short; apical pole broadly rounded, basal pole capitated to subcapitated; axial area hyaline with a visible line in some specimens; ribs absent; wings projection absent; fibulae short and large. L: 11.8-14.5 $\mu \mathrm{m}$; W: 4.5-6.4 $\mu \mathrm{m}$; L/M: 2.3-2.6; striae inconspicuous; F: $7-8$ in $10 \mu \mathrm{m}$.

This species resembles Surirella atomus Hustedt in its valve outline. However, S. stalagma forms populations with basal pole capitate and short fibulae, whereas $S$. atomus presents basal pole rounded and fibulae broad and short. S. atomus usually presents populations with smaller dimensions (L: $8-19 \mu \mathrm{m}$; W: 5-8 $\mu \mathrm{m}$; English, 2011).

Ecology: We have recorded this species in $0.8 \%$ of all samples in mesotrophic conditions, with water transparency ranging from 1.2 to 1.9 and $\mathrm{pH}$ from 6.6 to 6.9 .

Distribution: BRAZIL, São Paulo: Alto Paranapanema basin, Paineiras reservoir, S 2351'13.8" W 47³6'54.8”, G.C. Marquardt \& D.C. Bicudo (SP469450); Alto Tietê basin, Guarapiranga reservoir, S 23\%45'17.7" W 464'11.22”, S.B. Faustino \& D.C. Bicudo (SP428508).

Figures 28-30

\section{Surirella sp. 1}

Valve isopolar, linear or linear-lanceolate; keel high; valve ends rounded; axial area narrow, hyaline; ribs tenuous, parallel; fibulae distinct, parallel; striae delicate and visible in LM. L: 55.3-66.8 $\mu \mathrm{m}$; W: 8.9-10.1 $\mu \mathrm{m}$; L/M: 5.4-7.5; S: 15-19 in $10 \mu \mathrm{m}$; F: 4 in $10 \mu \mathrm{m}$.

This taxon is very similar to Surirella angusticostata Hustedt in Simonsen (1987) due to their valve outline, ribs parallel and valve ends rounded. However, Surirella sp. 1 presents visible wings projections.
Ecology: This taxon was presently found in $0.8 \%$ of all samples in oligotrophic waters, with water transparency of $1.8 \mathrm{~m}$ and $\mathrm{pH}$ of 6.4 .

Distribution: BRAZIL, São Paulo: Piracicaba, Capivari e Jundiaí basin, Atibainha reservoir, S 2308'50" W 4618'49" S.Z. Almeida \& D.C. Bicudo (SP469253).

Figures 16-18

Surirella sp. 2

Valve heteropolar, asymmetric; keel short; apical pole broadly rounded, basal pole cuneate; ribs absent; wing projections distinct, parallel; fibulae absent. L: 17-31 $\mu \mathrm{m}$; W: 6-13 $\mu \mathrm{m}$; L/M: 2.4-2.8; striae inconspicuous; WP: $4-5$ in $10 \mu \mathrm{m}$.

This taxon resembles Surirella pseudotenuis Cholnoky reported in Cocquyt et al. (2017) on its valve outline. However, $S$. pseudotenuis is narrower (W: 7.0-9.6 $\mu \mathrm{m}$ ) than Surirella sp. 2.

Ecology: This taxon was registered in $1.6 \%$ of all samples and exclusively in oligotrophic conditions, with water transparency of $1.2 \mathrm{~m}$ and $\mathrm{pH}$ of 5.2.

Distribution: BRAZIL, Sáo Paulo: Alto Tietê basin, Rio Pequeno reservoir, S 2347.027' W 4626.188', S. Wengrat \& D.C. Bicudo (SP401589).

Figures 14-15

Surirella sp. 3

Valve heteropolar, asymmetric, lanceolate; keel low; apical pole broadly rounded, basal pole acute; ribs absent; wings projections small and distinct, not reaching the axial area; fibulae absent. L: 18.3-18.5 $\mu \mathrm{m}$; W: 5.9-6.7 $\mu \mathrm{m}$; L/M: 2.7-3.1; striae inconspicuous; WP: 4-6 in $10 \mu \mathrm{m}$.

This taxon resembles Surirella pseudotenuissima Leclerq (1983) and S. tenuissima Hustedt emend. Leclerq (1983) due to valve outline. However, Surirella sp.3 differs to S. tenuissima mainly by absence of axial area undulate and fibulae parallel. Surirella sp. 3 differs to Surirella pseudotenuissima due to its smaller populations (Surirella pseudotenuissima L: 27-57 $\mu \mathrm{m}$; W: 9.3-13 $\mu \mathrm{m}$ ) and absence of striae conspicuous.

Ecology: In this study, it was recorded in 1.6\% of all samples in mesotrophic conditions, with water transparency of $2.0 \mathrm{~m}$ and $\mathrm{pH}$ of 7.0.

Distribution: BRAZIL, Sáo Paulo: Rio Piracicaba basin, Jaguarí reservoir, S 22 $2^{\circ} 57.4 .8^{\prime}$ W 46 23.3', M.N. Nascimento \& D.C. Bicudo (SP427353).

Figure 21

Surirella sp. 4

Valve isopolar, symmetric; keel high; valve ends cuneate; axial area narrow; ribs parallel; wings projections large, distinct; fibulae absent. 
L: $87.4 \mu \mathrm{m}$; W: $30.6 \mu \mathrm{m}$; L/M: 2.9; striae inconspicuous; R: 4 in $10 \mu \mathrm{m}$; WP: 4 in $10 \mu \mathrm{m}$.

This taxon is similar to Surirella biseriata Brébisson due to its valve shape, narrow axial area and parallel ribs. However, S. biseriata presents apiculate poles (Wolle, 1890).

Ecology: This taxon was registered in $1.6 \%$ of all samples in oligotrophic conditions, with water transparency of 3.6 and $\mathrm{pH}$ of 7.1.

Distribution: BRAZIL, São Paulo: Rio Piracicaba basin, Jacareí reservoir, S $22^{\circ} 58.15^{\circ}$ W 46⒉3', M.N. Nascimento \& D.C. Bicudo (SP427354).

Partial RDA controlled for 12 significant and positive PCNM variables showed that environmental variables $(\mathrm{pH}, \mathrm{TP}, \mathrm{TN}, \mathrm{N}: \mathrm{P}$ ratio and $Z_{\text {eu }}: Z_{\text {max }}$ ratio) explained a total of $15 \%$ of the Surirellales species variation (Figure $2 ; \mathrm{R}^{2}$ adj.: 0.06 ; $\mathrm{p}<0.001)$. The first axis mainly ordinated the species in relation to $\mathrm{pH}$ and light availability $\left(Z_{\text {eu }}: Z_{\max }\right.$ ratio) values. Species related to slightly less acid waters and less light availability were placed in the positive side of axis 1 (Surirella sp. 4 and Surirella linearis var. constricta), whereas the ones more closely associated to higher light availability and more acidic waters were depicted in the negative side of this axis (Stenopterobia curvula, S. delicatissima and Stenopterobia sp. 1). Variation partitioning analysis revealed that the pure effect of the environmental and spatial predictors on Surirellales species structure was highly significant $(\mathrm{p}<0.001)$. Environment and space were responsible for $6 \%$ and $8 \%$, respectively, of species variation. The shared fraction was low $(1 \%)$, suggesting that the effects of environmental variables spatially structured were low. These findings indicate that the spatial distribution of environmental resources and conditions (e.g. light availability and $\mathrm{pH}$ ) has low effects in the occurrence of such species.

Regarding ecological range, almost all species showed the preference for slightly acidic waters, except for Stenopterobia sp. 1 and Surirella sp. 2 , which were found in more acidic waters ( $\mathrm{pH} 5.4$ and 5.2, respectively; Table 3). Besides, all taxa were mostly found in low nutrient waters $\left(\mathrm{TN}<784.7 \mu \mathrm{g} \mathrm{L}^{-1} ; \mathrm{TP}<35.2 \mu \mathrm{g} \mathrm{L}^{-1}\right)$, except for Surirella linearis that prefers to live in higher nutrients conditions $\left(\mathrm{TN}=1185.9 \mu \mathrm{g} \mathrm{L}^{-1}\right.$; $\left.\mathrm{TP}=81.2 \mu \mathrm{g} \mathrm{L}^{-1}\right)$.

Several studies have been reported the effects of the spatial distribution in diatoms (Heino et al., 2010; Soininen et al., 2004), but species of Surireralles were often neglected. It is not surprising that we presently found significant effects of spatial variables in some taxa studied (Table 3), since they are not ubiquitous species. Stenopterobia curvula, Stenopterobia sp. 1 and Surirella roba showed relatively high effects of space variables (determined by geographic distance), suggesting that this group could have a geographical distribution. Until recently, distribution of microorganisms was not attributed to spatial factors such as geographic distance, but this paradigm has been altered with new findings such as those in the present study, as well as other studies (e.g. Soininen 2007; Heino et al., 2010; Zorzal-Almeida et al., 2017a).

In conclusion, our study presents taxonomical and ecological information for 14 taxa of Surirellales, five of them probably being new species for science. Furthermore, our results corroborate general information about Surirellales from the literature demonstrating that, despite their low abundance and occurrence in samples, Surirellales species have preferences for oligo- and mesotrophic conditions, neutral or slightly acidic waters and higher light availability values. Moreover, our results suggest that some Surirellales species (e.g. Stenopterobia curvula) can show some degree of geographical distribution.

\section{Acknowledgements}

This study was carried out within the framework of the AcquaSed project supported by FAPESP (Fundação de Amparo à Pesquisa do Estado de São Paulo, grant no 2009/53898-9). ECRB and SZA thank their doctoral fellowship (FAPESP processes 2013/14337-7 and 2013/23703-7, respectively). Funding was also provided by $\mathrm{CNPq}$, Conselho Nacional de Desenvolvimento Científico e Tecnológico (grant 310404/2016-9 to DCB, 305031/2016-3 to CEMB and masters fellowship to KSM). We are also grateful to Prof. William de Queiróz (Universidade de Guarulhos, Laboratório de Geoprocessamento) for providing the illustration of the study area. Finally, we are deeply grateful to all the students and technicians from the Department of Ecology, Institute of Botany, involved in field and laboratory work.

\section{References}

AMERICAN PUBLIC HEALTH ASSOCIATION APHA. Standard methods for the examination of water and wastewater. Washington: APHA, 2005.

BARBER, H.G and HAWORTH, E.Y. A guide to the morphology of the Diatom Frustule with a key to British freshwater genera. Ambleside: Freshwater Biological Association, 1981. 
BARTOZEK, E.C.R., BUENO, N.C., LUDWIG, T.A.V., TREMARIN, P.I., NARDELLI, M.S. and ROCHA, A.C.R. Diatoms (Bacillariophyceae) of Iguaçu National Park, Foz do Iguaçu, Brazil. Acta Botanica Brasílica, 2013, 27(1), 108-123. http:// dx.doi.org/10.1590/S0102-33062013000100012.

BATTARBEE, R.W., JONES, V.J., FLOWER, R.J., CAMERON, N.G., BENNION, H., CARVALHO, L. and JUGGINS, S. Diatoms. In: J.P. SMOL, H.J.B. BIRKS and W.M. LAST, eds. Tracking environmental change using lake sediments. Kluwer: Dordrecht, 2001, pp. 155-202. Terrestrial, algal, and siliceous indicators, vol. 3 .

BICUDO, D.C., TREMARIN, P.I., ALMEIDA, P.D., ZORZAL-ALMEIDA, S., WENGRAT, S., FAUSTINO, S.B., COSTA, L.F., BARTOZEK, E.C.R., ROCHA, A.C.R., BICUDO, C.E.M. and MORALES, E.A. Ecology and distribution of Aulacoseira species (Bacillariophyta) in tropical reservoirs from Brazil. Diatom Research, 2016, 31(3), 2-17. http://dx.doi.org/10.1080/026924 9X.2016.1227376.

BORCARD, D., GILLET, F. and LEGENDRE, P. Numerical ecology with R. New York: Springer, 2011. http://dx.doi.org/10.1007/978-1-4419-7976-6.

BORTOLINI, J.C. and BUENO, N.C. Seasonal variation of the phytoplankton community structure in the São João River, Iguaçu National Park, Brazil. Brazilian Journal of Biology = Revista Brasileira de Biologia, 2013, 73(1), 1-14. http:// dx.doi.org/10.1590/S1519-69842013000100002. PMid:23644782.

CALIFORNIA ACADEMY OF SCIENCES. Diatom collection [online]. California, 2012 [viewed 07 May 2017]. Available from: http://research.calacademy. org/izg/research/diatom

CENTRO DE PESQUISAS METEOROLÓGICAS E CLIMÁTICAS APLICADAS A AGRICULTURA CEPAGRI. A classificação climática de Koeppen para o Estado de São Paulo [online]. 2015 [viewed 01 July 2017]. Available from: http://www.cpa.unicamp.br/ outrasinformacoes/clima-dos-municipios-paulistas. html

CHOLNOKY, B.J. Beiträge zur Kenntnis der Algenflora von Portugiesicg-Ost-Afrika (Moçambique). I Boletim da Sociedade Portuguesa de Ciências Naturais, 1952, 4(1), 89-135.

COCQUYT, C. and JAHN, R. Rare Surirella taxa (Bacillariophyta) from East Africa described by Otto Müller: typifications, recombinations, new names, annotations and distribution. Willdenowia, 2005, 35(2), 359-371. http://dx.doi.org/10.3372/ wi.35.35218.

COCQUYT, C. and TAYLOR, J.C. New and interesting Surirella taxa (Surirellaceae, Bacillariophyta) from the Congo Basin (DR Congo). European Journal of Taxonomy, 2015, 133, 1-15.
COCQUYT, C., TAYLOR, J.C. and KUSBER, W.H. Reinvestigation of African Surirella taxa (Bacillariophyta) described by B.J. Cholnoky with some remarks on digitization of diatom types. Fottea, 2017, 17(1), 34-56.

COCQUYT, C., TAYLOR, J.C. and WETZEL, C.E. Stenopterobia cataractarum sp. nov. (Bacillariophyta), a new benthic diatom from a waterfall in Zambia, Africa. Phytotaxa, 2014, 158(1), 76-84.

DRAY, S., LEGENDRE, P. and PERES-NETO, P.R. Spatial modelling: a comprehensive framework for principal coordinate analysis of neighbour matrices (PCNM). Ecological Modelling, 2006, 196(3-4), 483-493. http://dx.doi.org/10.1016/j. ecolmodel.2006.02.015.

DUDGEON, D., ARTHINGTON, A.H., GESSNER, M.O., KAWABATA, Z., KNOWLER, D.J., LÉVÊQUE, C., NAIMAN, R.J., PRIEURRICHARD, A.H., SOTO, D., STIASSNY, M.L. and SULLIVAN, C.A. Freshwater biodiversity: importance, threats, status, and conservation challenges. Biological Reviews of the Cambridge Philosophical Society, 2006, 81(2), 163-182. http://dx.doi.org/10.1017/S1464793105006950. PMid:16336747.

ENGLISH, J. Surirella atomus. In: U.S. DEPARTMENT OF THE INTERIOR, U.S. GEOLOGICAL SURVEY. Diatoms of the United States. Colorado: Diatoms of North America, 2011 [viewed 11 July 2017]. Available from http://westerndiatoms. colorado.edu/taxa/species/surirella_atomus

ESKINAZI-LEÇA, E.M., CUNHA, C.W.N., SANTIAGO, M.G.G.S., BORGES, M.F., LIMA, G.C.P., SILVA, J.C., FERREIRA, M.H., AQUINO, L.C., DA SILVA, E. and MENEZES, W.J. Bacillariophyceae. In: Instituto de Pesquisas Jardim Botânico do Rio de Janeiro. Lista de espécies da flora do Brasil [online]. Rio de Janeiro: COPPETECUFRJ, 2015 [viewed 11 July 2017]. Available from http://floradobrasil.jbrj.gov.br/reflora/floradobrasil/ FB98693

ESTEVES, F.A. Fundamentos de Limnologia. 2. ed. Rio de Janeiro: Interciência, 1998. 602 p.

FERREIRA, K.S.M. and BICUDO, C.E.M. Criptógamos do Parque Estadual das Fontes do Ipiranga, São Paulo, SP. Algae, 42: Bacillariophyceae (Surirellales). Hoehnea, 2017, 44(1), 10-28. http:// dx.doi.org/10.1590/2236-8906-34/2016.

FOGED, N. Diatoms in Alaska. Vaduz: J. Cramer, 1981. Bibliotheca Phycologica, no. 53.

FOURTANIER, E. and KOCIOLEK, J.P. Catalogue of diatom names [online]. 2011 [viewed 07 July 2017]. Available from http://research.calacademy.org/ research/diatoms/names/index.asp

FRENGUELLI, J. XVI Contribución al conocimiento de las diatomeas argentinas. Diatomeas del Río de 
La Plata. Revista del Museo de La Plata. Nueva Serie. Sección Botánica, 1941, 3(15), 213-334.

GILlETT, N.D., PAN, Y., MANOYLOV, K.M., STANCHEVA, R. and WEILHOEFER, C.L. The potential indicator value of rare taxa richness in diatom-based stream bioassessment. Journal of Phycology, 2011, 47(3), 471-482. http:// dx.doi.org/10.1111/j.1529-8817.2011.00993.x. PMid:27021976.

HEINO, J., BINI, L.M., KARJALAINEN, S.M., MYKRÁ, H., SOININEN, J., VIEIRA, L.C.G. and DINIZ-FILHO, J.Ã.A.F. Geographical patterns of micro-organismal community structure: are diatoms ubiquitously distributed across boreal streams? Oikos, 2010, 119(1), 129-137. http://dx.doi.org/10.1111/ j.1600-0706.2009.17778.x.

HUSTEDT, F. Systematische und ökologische Untersuchungen über die Diatomeen-Flora von Java, Bali und Sumatra nach dem Material der Deutschen Limnologischen Sunda-Expedition. I. Systematischer Teil. Archiv für Hydrobiologie, 1938, 15(2), 187-295. Supplement.

HUSTEDT, F. Die Diatomeenflora des Fluss-systems der Weser im Gebiet der Hansestadt Bremen. Abhandlungen der Naturwissenschaftlichen Verein zu Breme, 1957, 34(3), 181-440.

HUSTEDT, F. The Pennate Diatoms (a translation of Hustedt's "Die Kieselalgen, 2 Teil" by Norma Jensen). Koenigstein: Koeltz Scientif Books, 1985.

INSTITUTO BRASILEIRO DE GEOGRAFIA E ESTATÍSTICA - IBGE. O Estado de São Paulo [online]. Rio de Janeiro: IBGE, 2017 [viewed 8 June 2017]. Available from: http://www.ibge.gov.br

KRAMMER, K. and LANGE-BERTALOT, H. Bacilariophyceae: Bacillariaceae, Ephithemiaceae, Surirellaceae. In: H. ETTL, I. GERLOFF, H. HEYNING and D. MOLLENHAUER, eds. Süsswasserflora von Mitteleuropa. Stuttgart: G. Fischer, 1988. pp. 1-596.

KRAMMER, K. and LANGE-BERTALOT, H. Bacillariophyceae, 4. Teil, Achnanthaceae, Kritische Erganzungen zu Navicula/Lineolatae) und Gomphonema. In: H. ETTL, J. GERLOFF, H. HEYNIG and D. MOLLENHAUER, ed. Süsswasserflora von Mitteleuropa. Band 2. Jena: Gustav Fischer, 1991. pp. 6-595.

KÜTZING, F.T. Die kieselschaligen Bacillarien Oder Diatomeen. Nordhausen: New York Botanical Garden, 1844. http://dx.doi.org/10.5962/bhl. title.64360.

LANGE-BERTALOT, H. and METZELTIN, D. Oligotrophie-Indikatoren 880 taxas in drei ökologisch diversen Seen -Type. In: H. LANGE-BERTALOT, ed. Iconographia Diatomologica Annoted Diatom Micrographs. 2nd ed. vol. 5. Köenigstein: Koeltz Scientific Books, 1996. pp. 6-695.
LANGE-BERTALOT, H. Diatoms in springs from Central Europe and elsewhere under the influence of hydrogeology and anthropogenic impacts. In: A.R.G. GANTNER and K.G. VERLAG, eds. Iconographia Diatomologica. vol. 13. Köenigstein: A.R.G. Gantner, 2004. pp. 9-480.

LECLERCQ, L. Description et ecologie de nouveaux taxons de diatomees des genres Surirella et Achnanthes. Bulletin du jardin Botanique National de Belgique, 1983, 53(3-4): 491-505.

LECOINTE, C., COSTE, M. and PRYGIEL, J. "Omnidia": software for taxonomy, calculation of diatom indices and inventories management. Hydrobiologia, 1993, 269-270(1), 509-513. http:// dx.doi.org/10.1007/BF00028048.

LEGENDRE, P., BORCARD, D., BLANCHET, F.G., CACERES, M. and DRAY, S. MEM spatial eigenfunction and principal coordinate analyses. $R$ Package Version 2.1-4 [online]. Vienna: R-Forge, 2009 [viewed 24 July 2017]. Available from: http://RForge.R-project.org

LOWE, R.L. Keeled and Canalled Raphid Diatoms. In: J.D. WEHR and R.G. SHEATH, eds. Freshwater Algae of North America, ecology and classification. San Diego: Academic Press, 2003. pp. 669-684. http:// dx.doi.org/10.1016/B978-012741550-5/50020-9.

MARCHANT, R., HIRST, A., NORRIS, R.H., BUTCHER, R., METZELING, L. and TILLER, D. Classification and ordination of macroinvertebrate assemblages from running waters in Victoria, Australia. Journal of the North American Benthological Society, 1997, 16(3), 664-681. http://dx.doi. org/10.2307/1468152.

MEDLIN, L.K. and KACZMARSKA, I. Evolution of the diatoms V. Morphological and cytological support for the major clades and taxonomic revision. Phycologia, 2004, 43(3), 245-270. http://dx.doi. org/10.2216/i0031-8884-43-3-245.1.

MENEZES, M., BICUDO, C.E.M., MOURA, C.W.N., ALVES, A.M., SANTOS, A.A., PEDRINI, A.G., ARAÚJO, A., TUCCI, A., FAJAR, A., MALONE, C., KANO, C.H., SANT'ANNA, C.L., BRANCO, C.Z., ODEBRECHT, C., PERES, C.K., NEUHAUS, E.B., ESKINAZILEÇA, E., AQUINO, E., NAUER, F., SANTOS, G.N., AMADO FILHO, G.M., LYRA, G.M., BORGES, G.C.P., COSTA, I.O., NOGUEIRA, I.S., OLIVEIRA, I.B., PAULA, J.C., NUNES, J.M.C., LIMA, J.C., SANTOS, K.R.S., FERREIRA, L.C., GESTINARI, L.M.S., CARDOSO, L.S., FIGUEIREDO, M.A.O., SILVA, M.H., BARRETO, M.B.B.B., HENRIQUES, M.C.O., CUNHA, M.G.G.S., BANDEIRA-PEDROSA, M.E., OLIVEIRA-CARVALHO, M.F., SZÉCHY, M.T.M., AZEVEDO, M.T.P., OLIVEIRA, M.C., CABEZUDO, M.M., SANTIAGO, M.F., BERGESH, M., FUJII, M.T., BUENO, N.C., 
NECCHI JUNIOR, O., JESUS, P.B., BAHIA, R.G., KHADER, S., ALVES-DA-SILVA, S.M., GUIMARÃES, S.M.P.B., PEREIRA, S.M.B., CAIRES, T.A., MEURER, T., CASSANO, V., WERNER, V.R., GAMA JUNIOR, W.A. and SILVA, W.J. Update of the Brazilian floristic list of Algae and Cyanobacteria. Rodriguésia, 2015, 66(4), 1047-1062. http://dx.doi.org/10.1590/21757860201566408 .

METZELTIN, D., LANGE-BERTALOT, H. and GARCÍA-RODRÍGUEZ, F. Diatoms of Uruguay. In: H. LANGE-BERTALOT, ed. Iconographia Diatomologica. vol 15. Königstein, 2005. pp. 7-726.

OKSANEN, J., BLANCHET, F.G., KINDT, R., LEGENDRE, P., MINCHIN, P.R., O'HARA, R.B., SIMPSON, G.L., SOLYMOS, P., STEVENS, M.H.H., SZOECS, E. and WAGNER, H. Package 'vegan' [online]. 2017 [viewed 24 July 2017]. Available from: cran.r-project.org/web/packages/ vegan/vegan.pdf

OLIVEIRA, B.D., NOGUEIRA, I.S. and SOUZA, M.G.M. Stenopterobia e Surirella (Bacillariophyceae, Surirellaceae) do Sistema Lago dos Tigres, Britânia, Goiás. Rodriguésia, 2012, 63(3), 525-539. http:// dx.doi.org/10.1590/S2175-78602012000300004.

PERES-NETO, P.R. and LEGENDRE, P. Estimating and controlling for spatial structure in the study of ecological communities. Global Ecology and Biogeography, 2010, 19(2), 174-184. http://dx.doi. org/10.1111/j.1466-8238.2009.00506.x.

PONADER, K.C., CHARLES, D.F. and BELTON, T.J. Diatom-based TP and TN inference models and indices for monitoring nutrient enrichment of New Jersey streams. Ecological Indicators, 2007, 7(1), 79-93. http://dx.doi.org/10.1016/j.ecolind.2005.10.003.

POTAPOVA, M. and CHARLES, D.F. Benthic diatoms in USA rivers: distributions along spatial and environmental gradients. Journal of Biogeography, 2002, 29(2), 167-187. http://dx.doi.org/10.1046/ j.1365-2699.2002.00668.x.

R CORE TEAM. $R$ : a language and environment for statistical computing [online]. Vienna: R Foundation for Statistical Computing, 2016 [viewed 24 July 2017]. Available from: https://www.r-project.org/

RIVERA, P.R. Diatomeas de agua dulce de Concepción y alrededores (Chile). Gayana (Concepción), 1974, 28, 3-134.

ROSA, V.V. and GARCIA, M. Ecological guilds of epiphytic diatoms (Bacillariophyta) on Acrostichum danaeifolium Längst. \& Fisch in a subtropical wetland in southern Brazil. Acta Limnologica Brasiliensia, 2015, 27(3), 311-321. http://dx.doi.org/10.1590/ S2179-975X4214.

ROSS, R., COX, E.J., KARAYEVA, D.G., MANN, D.G., PADDOCK, T.B., SIMONSEN, R. and SIMS, P.A. An emended terminology for the siliceous components of diatom cell. Nova Hedwigia, 1979, 64, 513-533.

ROUND, F.E., CRAWFORD, R.M. and MANN, D.G. The diatoms biology and morphology of the genera. New York: Cambridge University Press, 1990.

RUCK, E.C. and THERIOT, E.C. Origin and evolution of the canal raphe system in diatoms. Protist, 2011, 162(5), 723-737. http://dx.doi.org/10.1016/j. protis.2011.02.003. PMid:21440497.

RUCK, E.C., NAKOV, T., ALVERSON, A.J. and THERIOT, E.C. Phylogeny, ecology, morphological evolution, and reclassification of the diatom orders Surirellales and Rhopalodiales. Molecular Phylogenetics and Evolution, 2016, 103, 155-171. http://dx.doi.org/10.1016/j.ympev.2016.07.023. PMid:27456747.

SALA, S.E., RAMÍREZ, J.J., VOUILLOUD, A.A. and PLATA-DÍAZ, Y. Surirella antioquiensis sp. nov. and S. rafaelii sp. nov. (Bacillariophyta) from Colombia. Acta Nova, 2013, 6(1-2), 17-35.

SALOMONI, S.E. and TORGAN, L.C. O gênero Surirella Turpin (Surirellaceae, Bacillariophyta) em ambientes aquáticos do Parque Estadual Delta do Jacuí, Sul do Brasil. Iheringia. Série Botânica, 2010, 2(65), 281-290.

SCHOEMAN, F.R. A systematical and ecological study of the diatom flora of lesotho with special reference to the water quality. Pretoria: V\&R Printers, 1973.

SILVA, A.M., LUDWIG, T.A.V., TREMARIN, P.I. and VERCELLINO, I.S. Diatomáceas perifíticas em um sistema eutrófico brasileiro (Reservatório do Iraí, estado do Paraná). Acta Botanica Brasílica, 2010, 24(4), 997-1016. http://dx.doi.org/10.1590/ S0102-33062010000400015.

SIMONSEN, R. Atlas and catalogue of diatoms types of friedrich hustedt. Berlin: J. Cramer, 1987.

SMITH, V.H., JOYE, S.B. and HOWARTH, R.W. Eutrophication of freshwater and marine ecosystems. Limnology and Oceanography, 2006, 51(1), 351-355. Part 2. http://dx.doi.org/10.4319/lo.2006.51.1_ part_2.0351.

SOININEN, J. Environmental and spatial control of freshwater diatoms - a review. Diatom Research, 2007, 22(2), 473-490. http://dx.doi.org/10.1080/026924 9X.2007.9705724.

SOININEN, J., PAAVOLA, R. and MUOTKA, T. Benthic diatom communities in boreal streams: community structure in relation to environmental and spatial gradients. Ecography, 2004, 27(3), 330-342. http://dx.doi.org/10.1111/j.09067590.2004.03749.x.

TORGAN, L.C. and WEBER, A.S. Novos registros de Surirella Turpin (Bacillariophyta, Surirellaceae) para o Rio Grande do Sul e Brasil. Acta Botanica Brasílica, 2008, 22(2), 393-398. http://dx.doi.org/10.1590/ S0102-33062008000200009. 
VIRTANEN, L. and SOININEN, J. The roles of environment and space in shaping stream diatom communities. European Journal of Phycology, 2012, 47(2), 160-168. http://dx.doi.org/10.1080/096702 62.2012.682610.

WOLLE, F. Diatomaceae of North America, illustrated with twenty-three hundred figures from the author's drawings on one hundred and twelve plates. Wolle Francis 1817-1893, 1890. CIHM/ICMH Microfiche Series, 33166. https://doi.org/10.5962/bhl.title.45949.

ZORZAL-ALMEIDA, S., BINI, L.M. and BICUDO, D.C. Beta diversity of diatoms is driven by environmental heterogeneity, spatial extent and productivity. Hydrobiologia, 2017a, 800(1), 7-16. http://dx.doi.org/10.1007/s10750-017-3117-3.

ZORZAL-ALMEIDA, S., SOININEN, J., BINI, L.M. and BICUDO, D.C. Local environment and connectivity are the main drivers of diatom species composition and trait variation in a set of tropical reservoirs. Freshwater Biology, 2017b, 62(9), 15511563. http://dx.doi.org/10.1111/fwb.12966.

Received: 24 July 2017 Accepted: 23 April 2018 